\title{
Anthropogenic activity and regional vulnerability to change: The case of Sardinia (Italy)
}

\author{
Camerada Maria Veronica \\ Department of Humanistic and Social Sciences, University of Sassari, Italy
}

Email address:

vcamerada@uniss.it

To cite this article:

Camerada Maria Veronica. Anthropogenic Activity and Regional Vulnerability to Change: The Case of Sardinia (Italy). Social Sciences. Special Issue: Geographical evidence in changing Europe. Vol. 3, No. 4-1, 2014, pp. 74-78. doi: 10.11648/j.ss.s.2014030401.18

\begin{abstract}
The paper contributes to the debate on the relationship between economic growth and environmental limits. The analysis is conducted on a regional scale and focuses on the development of a pressure indicator which is the correlation between the performance (in Added Value terms) of each economic anthropogenic activity and its relative level of pollution. Using a comparison between the results produced by the pressure indicator and other indicators used in the literature, it is possible to work out a more coherent view of the regional relationship between climate change and economic growth.
\end{abstract}

Keywords: Climate Change, Regional Vulnerability, Carbone Impact, Sardinia

\section{Introduction}

Climate change and its impact on growth and development in recent years takes a central importance in the overall context of spatial planning. More precisely, the climate change governance requires a complex mix-and-match between administrative public system and private sector for a joint action that aims at effective and timely transition from the traditional economy to a low-carbon one [24.16]. From a sustainable development perspective, climate change needs adaptation measures to revise its effects and mitigation measures to reduce emissions. It means that the climate question necessitates a synergistic work between private-public and mitigation-adaptation looking at the problem of mismatch in term of spatial and temporal scales [8]. Cross, in this issue, the different dimensions of analysis: environmental alarm, limits to growth, the costs of qualified growth, roles and responsibilities [15.18.15.6.7]. A sustainable approach recalls the fundamental theory of externalities and public goods, and invites the research to produce future scenarios. Among all those processed, one must certainly be avoided: the "business as usual" era.

In this paper the author undertakes a new research field providing a contribution to the copious existing specific literature. In this research the climate change question is faced by pondering over the evidences of international studies (ESPON projects, IPCC reports, etc.) and by working out specific indicators to analyse the territorial vulnerability in an Italian specific area: the island of Sardinia.

\section{Climate Change: From the Global Question to the Case of Sardinia}

In the following analysis the territorial vulnerability on climate change of the Sardinian area will be examined by a PSR model. The Pressure indicator, calculated as the covariance between the production assets and the related Added Value and GHG emissions, provides a clear indications about of the environmental stress caused by human activities, on a local scale. It explains the real relationship between the regional economic growth and the pollution connected to local GHG emission and it suggests in which economic sector and scale the policy strategy (Response) for mitigation is required. State indicators relate to the quality of the environment and the natural resources. In this research it is documented, at regional level, by the Environmental Sensitive Areas Index (ESAI) [2].

\subsection{GHG Emission and Climate Variation}

The Fifth to reduce emissions Assessment Report on the Physical Science Basis for climate change [13], which detects the worldwide distribution of changes in average temperature over the period 1901-2012, noted increases in heat around the planet, in average about $0,85^{\circ} \mathrm{C}$ but sometimes more than $2^{\circ}$ $\mathrm{C}$ and defines "extremely probable " that human activity is the main cause of the increase in global average temperatures at 
the surface (TMGS). From the industrial revolution global atmospheric concentrations of the gases $\mathrm{CO}_{2}, \mathrm{CH}_{4}, \mathrm{~N}_{2} \mathrm{O}$ have increased At respectively by $40 \%, 150 \%$, and $20 \%$, causing a systematic increase in temperature.

In the IPCC study, four CPR (Representative Concentration Pathways) are elaborated: a scene of strong mitigation (RCP2.6), two stabilization scenarios of greenhouse gas emissions (RCP4.5 and RCP6) and a scene with high emissions (RCP8.5). Each one provides for the implementation of possible climate change policies at the global level. It's been that the estimated increase in global average temperatures at the surface (TMGS) for the period 2016-2035 will be in the range of $0.3^{\circ} \mathrm{C}-0.7^{\circ} \mathrm{C}$ for all four RCP.

The results produced by the ESPON Climate project highlights the close link between land development and climate change, and underlines the consequences on local economies and regional competitiveness brought on by climate change.

This case study refers to Sardinia, that in the above cited ESPON project is included in the Mediterranean typology of climate region ${ }^{1}$, and is considered an area of medium-high potential vulnerability to climate change ${ }^{2}$. The analysis here also takes into account studies by $\mathrm{N}$. Stern [24] who analyzed climate change with an economic perspective, and provided the starting points for a transition from traditional forms of economy towards a low carbon economy. The Stern Review emphasizes the importance of immediate action on a global scale and highlights the uncertain condition in which choices and strategy policy must be made. In fact, although the environmental goods perfectly fulfill an economic function, they are not contemplated in the traditional market model function. This is explained by the fact that for traditional goods in a competitive market, the mechanism of pricing is closely related to the function of supply and demand. This means that the availability and demand for goods automatically acts on the price, which in turn acts on supply and demand. In contrast, environmental goods are freely available, and the wide availability precludes an automatic pricing. This mechanism, known as "market failure" complicates the process of economic valuation of environmental goods, and also makes it difficult to quantify the economic depreciation related to their decay. It follows that the direct assessment of climate change is not objectively defined in economic terms. At the same time it results in the complex evaluating of the extent and the consequences of this phenomenon, which is still being studying. The scientific community agrees on the need to take immediate steps to reduce greenhouse gas emissions, as it supports the positive

\footnotetext{
1 Typology of climate change regions are developed by ESPON Climate project through a cluster analysis based on IPCC CCLM model (2071-2100), A1B scenario.

${ }^{2}$ See Potential vulnerability to climate change, in which vulnerability is calculated as the combination of regional potential impacts of climate change and regional capacity to adapt to climate change.
}

correlation between human activity and the GHG concentration $^{3}$, in that GHG grows proportionally to the increase of GDP per capita [25] $]^{4}$. At present it has not been established exactly to what extent the accumulation of GHG produced by human activity affects the climate, because the GHG are inherently variable due to the orbital motion of the earth around the sun. [4], but "There is a compelling scientific consensus that since the dawn of the industrial era human activity has become increasingly responsible for the changing climate" $[8$, xix]. Before the Industrial Revolution level of GHG in the atmosphere was 280 parts per million (ppm), in 2008 the level was 430ppm; it's estimated that in 2030 it gets 550ppm. It's also estimated that the cost of reducing emissions could be limited to around $1 \%$ of annual global GDP, while the unabated climate chance could cost about $20 \%$ of global GDP [24].

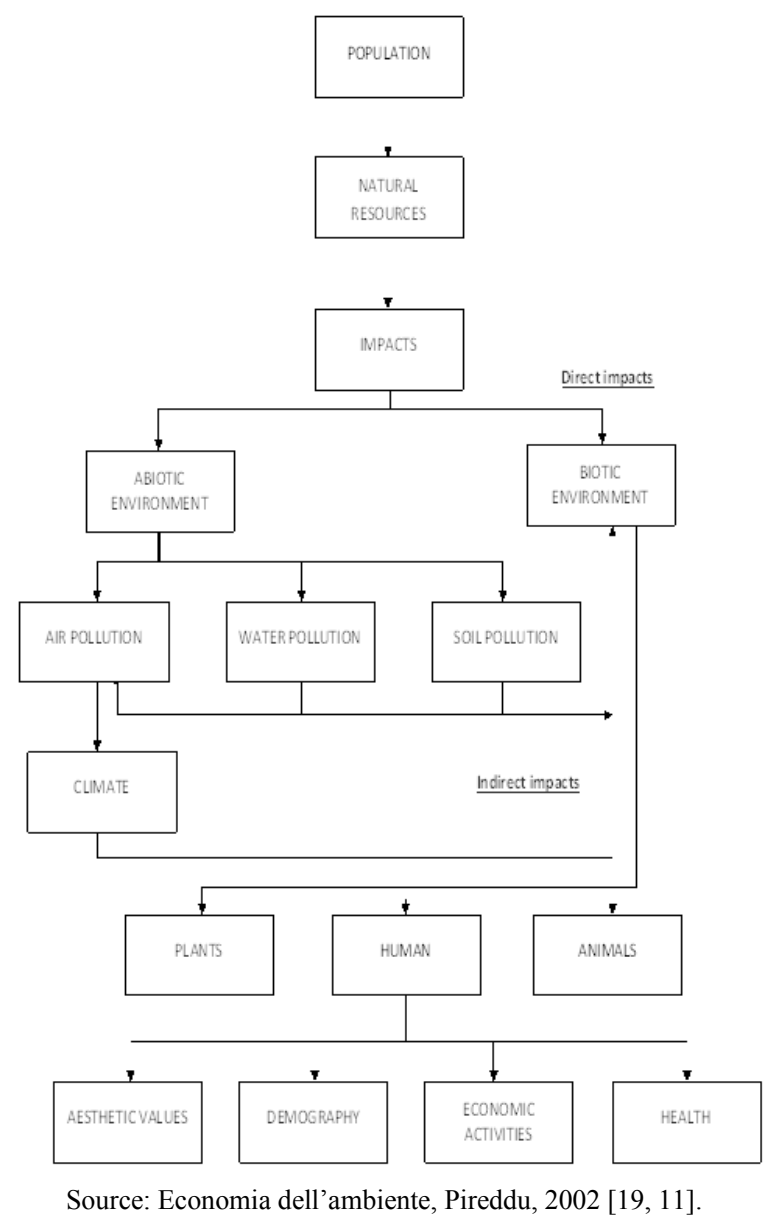

Fig. 1. Direct and indirect impacts of the anthropogenic activity on environment

\footnotetext{
${ }^{4}$ Richard York (Department of Sociology and Environmental Studies Program -University of Oregon) studied how the GHG emissions are influenced by the economy. the Gross Domestic Product (GDP) of more 150 nations during the period 1960-2008. He has found that for $1 \%$ growth in the GDP)per capita, the emission of greenhouse gases increased of $0.73 \%$ while there was about $0.43 \%$ of reduction in emissions for every $1 \%$ decline in GDP per capita.
} 
In light of the foregoing, in the study that follows, climatic variations are analysed in relation to the consequences they produce in an indirect way (Figure 1) $[19,11]$. In essence, the problem of economic valuation of natural capital (and in this case the modifications suffered as a result) is not exceeded by estimating the effects recorded in the natural system, but within a subsystem in this interconnected (e.g. anthropogenic social, urban, etc.). Here, we chose to focus the study on the economic subsystem, and to analyse the relationship between climate change and economic activities.

\section{Methodology}

\subsection{Pressure Indicators (PI), (VOC)}

The study confronts the problem of climate change in Sardinia according to the PSR model. It is purposely chosen for its use of indicators of environmental sustainability not considered in the ESPON Climate project. The choice of indicators was made considering the peculiarities of the territory studied and the need to acquire background information in view of possible policy actions to be put in place. The selection of indicators has been calibrated to ensure that two different perspective of the same problem come up: on the one hand they wanted to address the issue of the climate change in relation to human action exerted from local populations, on the other to frame the problem at its most global, checking the effects locally of global human activity.

The first type of indicators tends to check the level of environmental stress caused by the anthropogenic local action. Pressure Indicators (PI) (COV) (Figure. 2).

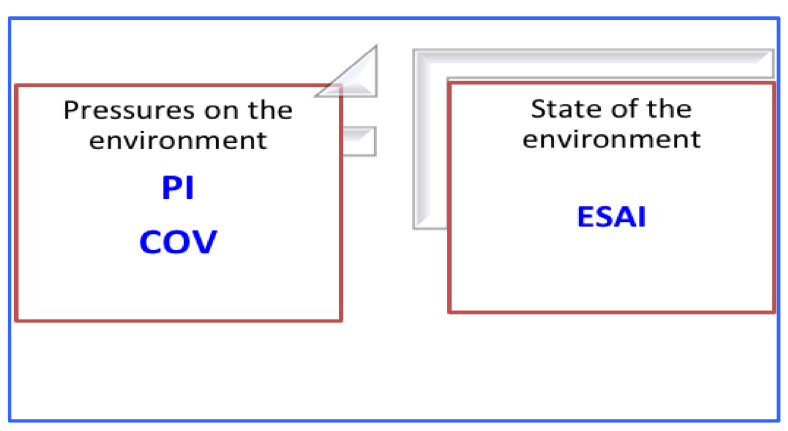

Fig. 2. PSR analysis: Pressure and State index

State indicators were instead used to analyze the level of land degradation of the territory under study, focusing on problems engendered by geoclimatic factors of the place, but also on the local effects caused by human activities globally. It was decided in this study to give space to a serious environmental problem that plagues Sardinia (and peninsular Italy) to a considerable extent compared to the rest of the nation: the desertification Status Indicators (ESAI).

\subsection{Pressure Indicators (PI), (COV)}

The indicator PI explains the level of emissions of GHG produced by each economic activity; the covariance (COV) relates Added Value, (AV) to the PI. Looking at figure 3, the first column lists all the economic activity done in Sardinia, grouped by categories. Each is given: Added Value, relevant employment, related emissions of pollutants emitted into the atmosphere. It should be noted the negative correlation between the variables PI and COV. It is possible to say, therefore, that exercised economic activities in Sardinia, which involved the largest number of workers, are those with low environmental impact. If you look at the national context, Sardinia proves to be one of the regions most virtuous in this sense. It is believed that this type of analysis, not covered in the ESPON Climate project, can be considered a valuable tool for planning and promoting productive activities with low environmental impact, coherent with "green" economic models with low carbon emissions. Furthermore it is interesting to note the incidence levels of methane produced by economic activities related to the primary sector. These activities are equal to a rate of $3.37 \%$ of the total regional Added Value,, but affect significantly in terms of the GHG emission.

\subsection{State Indicators (ESAI)}

The Environmental Sensitive Areas Index [2] identifies areas susceptible to desertification. This indicator was developed by the Regional Specialist Idrometeoclimatic Department. The ESAI is constructed by calculating the geometric mean of the scores awarded to 4 variables (soil, vegetation, climate, land management) using the following index: SQI, Soil Quality Index, CQI, Climate Quality Index, VQI, Vegetation Quality Index, MQI, Management Quality Index). Eight areas of sensitivity have been identified, with different levels of intensity, from "critical" to "not subject". The criticality and the fragility measured is expressed in three decreasing levels, which are respectively: C3, C2 and F3, F2, F1 (figure 4 and 5). 


\begin{tabular}{|c|c|c|c|c|c|c|c|c|c|c|c|c|c|c|c|c|c|c|}
\hline Economic activities & $\begin{array}{c}\text { Added } \\
\text { Value at } \\
\text { basic } \\
\text { prices } \\
\text { (Millions } \\
\text { euro) } \\
\end{array}$ & $\begin{array}{l}\text { Added } \\
\text { Value at } \\
\text { basic } \\
\text { prices \% }\end{array}$ & $\begin{array}{l}\text { Households } \\
\text { (Million euro) }\end{array}$ & $\begin{array}{c}\text { Units of } \\
\text { full-time } \\
\text { work } \\
\text { (Aanual } \\
\text { average in } \\
\text { thousanss) }\end{array}$ & $\begin{array}{l}\text { Greenhou } \\
\text { sefffect } \\
\text { (Thousandso } \\
\text { ftons of } \mathrm{CO}_{2} \\
\text { equivalent) }\end{array}$ & $\begin{array}{c}\text { Tropospheric } \\
\text { ozone } \\
\text { (tons of potential } \\
\text { for groundtevel } \\
\text { ozone) }\end{array}$ & $\begin{array}{c}\text { Methane } \\
\mathrm{CH}_{4} \\
\text { (t) }\end{array}$ & $\begin{array}{l}\text { Carbon } \\
\text { Monoxid } \\
\text { e co } \\
\text { (t) }\end{array}$ & $\begin{array}{l}\text { Carbon } \\
\text { Monoxid } \\
\text { eCO } \\
\text { (thuosand } \\
\text { t) }\end{array}$ & $\begin{array}{c}\text { Nitrous } \\
\text { Oxide } \\
\mathrm{N}_{2} \mathrm{O} \\
(\text { t) }\end{array}$ & $\begin{array}{l}\text { Ammoni } \\
\mathrm{a} \mathrm{NH}_{3} \\
(\mathrm{t})\end{array}$ & $\begin{array}{l}\text { Nitrogen } \\
\text { Oxides } \\
\mathrm{NO}_{\mathrm{x}} \\
(\mathrm{t})\end{array}$ & $\begin{array}{l}\text { Lead } \\
\mathrm{Pb} \\
(\mathrm{Kg})\end{array}$ & $\begin{array}{l}\text { Particulat } \\
\text { e PM10 } \\
\text { (t) }\end{array}$ & $\begin{array}{c}\text { Oxides } \\
\text { of Sulfur } \\
\text { SO }_{x} \\
(t)\end{array}$ & $\sum$ & $\begin{array}{c}P I \\
\text { Index } \\
\%\end{array}$ & Cov. \\
\hline \begin{tabular}{|l} 
Families - Transport \\
\end{tabular} & & & $\begin{array}{l}2.748,40 \\
2.73,80 \\
4.1380\end{array}$ & & $\begin{array}{r}1.523,54 \\
771,49\end{array}$ & $\begin{array}{r}37.239,64 \\
3.661 .56\end{array}$ & $\begin{array}{l}744,65 \\
662,49\end{array}$ & $\begin{array}{l}79.115,00 \\
1471400\end{array}$ & $\begin{array}{ll}1.454,08 \\
, 7253\end{array}$ & 173,63 & 420,98 & $4.566,20$ & & $\begin{array}{c}449,84 \\
69039\end{array}$ & $\begin{array}{lll}23,85 \\
50975\end{array}$ & $86.948,23$ & 31,10 & \\
\hline Families- Heating & & & ${ }^{4.313,80}$ & & 771,49 & $3.61,56$ & 662,49 & & 742,53 & 48,54 & & 692,96 & 36,63 & 640,39 & 507,61 & $18.045,15$ & 6,45 & \\
\hline Families - other & & & 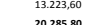 & & $\begin{array}{r}18,09 \\
231311\end{array}$ & $\begin{array}{r}4.925,52 \\
45,85272\end{array}$ & & 93.82900 & $\begin{array}{r}15,35 \\
22196\end{array}$ & $\begin{array}{r}8,81 \\
8309\end{array}$ & 420.99 & 525916 & 36.63 & 109022 & 531.46 & $\begin{array}{r}24,16 \\
1050755\end{array}$ & 0,01 & \\
\hline Families - Total & & & $20.285,80$ & & & $45,826,72$ & $1.407,14$ & (39.83,25,00 & $2.211,96$ & (20,0,939 & $y_{0}$ & 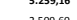 & 然, & 1.000,22 & 年 & 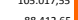 & 37,56 & $(10,77)$ \\
\hline Agriculture, hunting and forestry & 925,812 & 佛 & & ${ }_{49,60}$ & $2.645,78$ & $5.668,73$ & $55,980,72$ & $8.146,40$ & 219,70 & $4.033,82$ & $16.672,06$ & $2.509,60$ & 1,95 & 843,48 & 4,92 & $88.412,65$ & 31,62 & $(26,97]$ \\
\hline Fishing, fish farming and related service activities & ${ }_{95,12}$ & 0,35 & & ${ }^{4,40}$ & 47,57 & 900,35 & ${ }^{4,19}$ & ${ }^{246,78}$ & 47,18 & ${ }^{0,99}$ & 0,10 & 632,81 & 0,03 & 67,82 & 1,12 & ${ }_{1.001,02}$ & 0,36 & $(17,98 \mathrm{~g}]$ \\
\hline Mining and quarrying & 149,00 & 0,54 & & 3,00 & 99,92 & 309,23 & 985,55 & 77,24 & 77,77 & 4,69 & 0,11 & 214,61 & 0,72 & 19,74 & 221,91 & 1.602,34 & & (19,878] \\
\hline Food, beverages and tobacco & 453,49 & 1,65 & & 11,60 & 855,79 & $1.760,59$ & 394,24 & 129,40 & 844,55 & 9,53 & 0,10 & 363,31 & ${ }_{1,03}$ & 30,75 & 341,40 & 2.114,31 & & $(21,82]$ \\
\hline Textilies and wearing apparel & 98,53 & 0,36 & & ${ }^{4,60}$ & 75,19 & 23,61 & 150,41 & 4,66 & 71,90 & 0,41 & 0,01 & 14,09 & 0,07 & 1,68 & & 320,88 & & {$[24,18]$} \\
\hline Tanneries, manufacture of leather products, leather and leather products & 6,84 & 0,02 & & 0,30 & 36,30 & 544,54 & 7,13 & 12,85 & 35,83 & 1,03 & 0,01 & 30,06 & 0,04 & 2,44 & & 93,62 & & $(27,34)]$ \\
\hline Manuffacture of wood, ruber, plastics and other manufatcuring indus & 245,19 & 0,89 & & 9,10 & 97,68 & 874,36 & 1,72 & 65,60 & 96,31 & 4,30 & 0,07 & 149,09 & 0,09 & 13,17 & & 338,15 & & $(30,95]$ \\
\hline Manuffacture of pulp, paper and paper rododucts, printing and publishing & 106,99 & 0,39 & & 2,50 & 22,36 & 255,04 & 5,24 & ${ }_{11,93}>{ }_{1}$ & 22,05 & 0,63 & $0,01 \mathrm{C}$ & 28,42 & 0,03 & 2,35 & & 117,92 & & $(35,33)$ \\
\hline Coke, refined petroles & ${ }_{448,30}$ & 1,63 & & 5,80 & $7.340,19$ & ${ }_{13.071,61}$ & 3.926,98 & 964,73 & 7.230 .36 & $88.28 \mathrm{Y}$ & 1.03 & $6.999,10$ & 84,75 & 554,51 & $14.031,2: 2$ & 33.880 .97 & 12,12 & ${ }_{(40,344}$ \\
\hline Manufacture of ther non-metallil mineral processing & 262,10 & 0,95 & & 5,70 & $2.281,37$ & 3.7.74,93 & ${ }_{61,43}>2$ & $2.459,40$ & $2.238,16$ & 135,21 & 2.48 & 2.768 .60 & $1.130,45$ & 624,22 & 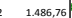 & 10.906,71 & & $36.56] \mathrm{C}$ \\
\hline Manufacture of basic metals and tabricated metal pre & 326,82 & 1,19 & & 10,50 & 1.256 .56 & $6.741,25$ & 32,45 & $21.397,00$ & $1.243,63$ & 39,49 & 9,72 & $2.977,40$ & $6.307,86$ & 408,69 & 6.754 .4 & $39.170,73$ & & 39,100 \\
\hline Manufacture of machinery and mechanical appliances, ele & ${ }_{454,74}$ & 1,65 & & 11,70 & 62.98 & 698.56 & 1,64 & 29,74 & 62,43 & 1,65 & 0,04 & ${ }_{71,88}>2$. & ${ }_{18,49}>\mathrm{C}$ & ${ }_{4,82}$ & & 193,70 & & (31,311 \\
\hline Production and distribution of electricty,y, gas, steam and water & $1.041,36$ & 3,79 & & 5,10 & $7.707,06$ & $7.668,22$ & 291,93 & $2.128,00$ & $7.692,26$ & 27,96 & 13,69 & $5.821,30$ & 205,14 & 414,98 & $8 \quad 10.243,28$ & $26.838,54$ & 9,60 & $(37,01]$ \\
\hline |construction & $1.897,06$ & 6,90 & & 52,40 & 87,76 & $2.327,60$ & ${ }_{4,44}>$, & 27,55 & 84,19 & 11,24 & 0,36 & 505,19 & 0,03 & 228,53 & ${ }_{23,83}$ & $1.137,36$ & 0,41 & $(34,70)$ \\
\hline Wholesale and retail trade, repair of motor vehicles, mototrcycles and personal and housenold & $3.064,76$ & ${ }_{11,14}$ & & 87,10 & ${ }_{436,17}$ & 3.998,15 & 22,39 & $1.074,20$ & ${ }_{423,89}$ & 38,08 & 2,17 & $2.348,70$ & 0,09 & 229,11 & 12,38 . & 4.151,01 & & $(39,76]$ \\
\hline Hotels and restaurants & $1.303,55$ & ${ }_{4,74}$ & & ${ }_{44,00}$ & 50,80 & 374,28 & ${ }^{4,67}$ & 129,45 & ${ }_{48,71}$ & 6,45 & 0,22 & 265,41 & 0,09 & 26,18 & & ${ }_{484,02}$ & 0,17 & $(46,60)$ \\
\hline Transport, storage and communication & $2.062,33$ & 7,50 & & ${ }_{41,30}$ & 1.593,04 & $21.664,24$ & 106,69 & 9.099,10 & 1.560,96 & 96,25 & ${ }_{4,69}$ & 15.036,00 & ${ }_{133,48}$ & 1.594,01 & 8.168,6: & 35.799,81 & 12,80 & $(57,55)$ ( \\
\hline Financial intermediation & 905,87 & 3,29 & & ${ }_{11,00}$ & 13,49 & 99,56 & 0,79 & 33,22 & ${ }_{13,12}$ & 1,13 & 0,07 & 70,44 & 0,06 & 6,79 & 1,4 & ${ }_{127,10}$ & 0,05 & $(37,82]$ \\
\hline Real estate, renting, research and other bu & 5.454,96 & 19,83 & & 57,60 & 163,71 & $1.204,87$ & 9,29 & 402,19 & 159,21 & 13,90 & 0,80 & 853,16 & 0,55 & ${ }_{81,84}$ & & $1.53,69$ & $0,55 \mathrm{~S}$ & $(45,98]$ \\
\hline Public administration and defense, compulsory social security & $3.049,72$ & ${ }_{11,09}>2>3$ & & 52,80 & 96,55 & 922,12 & 12,80 & $1.778,10$ & 92,96 & ${ }_{11,04}$ & 0,14 & 506,22 & 2,58 & 57,36 & & $2.517,85$ & 0,90 & [61,94] \\
\hline education & $2.001,09$ & 7,27 & & ${ }_{51,90}$ & 22,72 & 93,69 & 2,33 & 32,45 & 22,27 & 1,27 & 0,05 & 67,02 & 0,77 & ${ }_{6,11}$ & & ${ }_{147,86}>2$ & 0.05 & ${ }_{(91,81]}$ \\
\hline Health and other social services & $2.233,83$ & 8,12 & & 42,40 & 56,70 & 202,98 & 3,68 & 70,77 & 36,50 & 6491 & 0,12 & 144,41 & $0,83$. & 13,42 & 17,26 기 & 351,90 & 0,13 & $(170,99)$ \\
\hline Other community, social and personal services & 609,99 & 2,22 & & 22,00 & 727,97 & $1.581,62$ & $26.516,39$ & 111,51 & 109,96 & 197,32 & 290,35 & ${ }_{441,21}$ & 566,94 & 30,46 & 91,51 & $28.355,65$ & 10,14 & $(501,35)$ \\
\hline \begin{tabular}{|l} 
Domestic services for households \\
\end{tabular} & 310,50 & 1,13 & & 24,20 & & & & & & & & & & & & & & \\
\hline Economic activities - Total & $27.507,96$ & 100,00 & & 610,60 & $25.777,75$ & $74.680,12$ & $88.527,12$ & $48.684,26$ & 522.433,91 & 4.789,60 & 16.998,39 $>$ $>$ & $42.818,03$ & $8.456,06$ & $5.262,46$ & $41.629,99$ & $279.599,82$ & 100,00 & \\
\hline
\end{tabular}

Source: Our elaboration on Istat data, 2012

Fig. 3. Sardinia, Economic activities, Added Value, GHG Emissions and PI

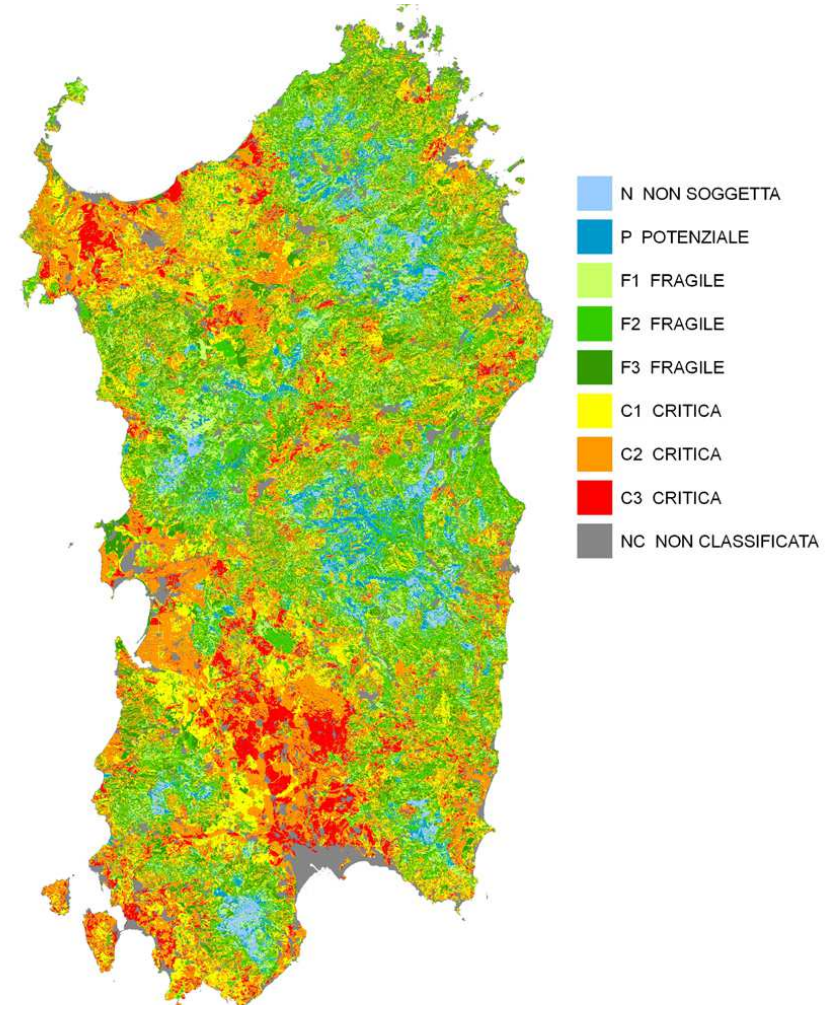

Source: Regional Specialist Idrometeoclimatic Department, 2009 [2]

Fig. 4. Sardinia, Map of sensitivity to desertification

Figures 4 and 5 show the level of desertification within the Sardinian territory: $46 \%$ of the examined area is highly degraded and $40 \%$ is on the edge of decay.

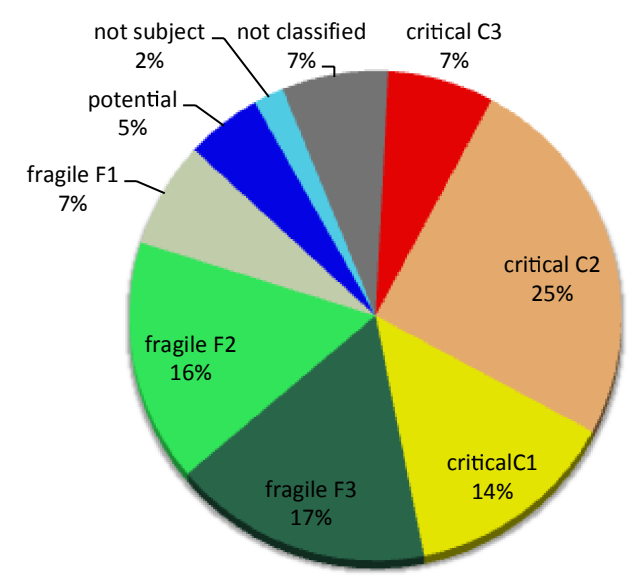

Source: Regional Specialist Idrometeoclimatic Department, 2009 [2]

Fig. 5. Sardinia, Map of sensitivity to desertification

\section{Conclusions}

The process of desertification is a complex phenomenon because its origins and consequences are both local and global. The direct causes concern climatic events and anthropogenic factors such as drought, forest fires, over-exploitation of soil and water resources, urbanization and rising temperatures. The consequence of this process is shown over the years, and assumes an irreversible character. Along with the erosion of the littoral is the progressive sterility of the land, resulting in the loss of value in the use and the production value of the land.

Moreover, emphasis in assessing the issue of climate change with an economic perspective, it is worth mentioning the results of a study concerning the implications of climate change in agricultural crops, in Sardinia. The scenario (B2; 2070-2099) is that of a gradual increase in the average temperature of about $2^{\circ} \mathrm{C}$ and a progressive reduction of 
land capacity by about $37 \%$ [10].

Finally, in this research the author begins to embarks on the climatic changing analysis to contribute to existing studies to explain the climate change impact on specific territories. In this analysis specific indicators are interlocked to point out the relationship between the variables anthropogenic activity and GHG emissions. The indicators show the low environmental impact of the economic activities carried out on the island. The evidence leads to suggestion that the Sardinia desertification problem is a consequence, in a greater measure, of a global question. For this reason the policies developed at the local level may not have the strength to fight against this phenomenon.

\section{Acknowledgements}

We gratefully acknowledge the Italian ESPON Contact Point for the constant work of capitalization and dissemination of ESPON results and for the backing given to the scientific community.

\section{References}

[1] D. Baker, G. Marstom and L. McClure, "Synergies and Goal Conflicts for Climate Change Policy and Spatial Planning", in M. Schrenk, V. Popovich, P. Zeile \& P. Elisei, (Eds.) Proceedings of REAL CORP 2013 - The 18th International Conference on Urban Planning, Regional Development and Information Society, CORP - Competence Centre of Urban and Regional Planning, Acquario Romano (House of Architecture) Rome, Italy, 2013, pp. 871-877.

[2] G. Bianco et al., "Aggiornamento e completamento della cartografia di scala 1: 1000.000 delle aree sensibili alla desertificazione in Sardegna", ARPAS, Dipartimento Specialistico Regionale Agrometoclimatico, 2009.

[3] P. Bond, "Emissions Trading, New Enclosures and Eco-Social Contestation", Antipode, Volume 44, Issue 3, June 2012, DOI: $10.1111 / j .1467-8330.2011 .00890 . x$ pp. 684-701.

[4] A. Baracca, M. Fischietti and R. Rigatti, "Fisica e realtà. L'uomo e l'energia”, Capelli Editore, Bologna, 2004.

[5] R. Coase, "The Problem of Social Cost", Journal of Law and Economics, Vol. 3 (1), October 1960, pp. 1-44.

[6] M. E. Colby, " Environmental management in development: the evolution of paradigms", Ecological Economics, 3, 1991, pp 193-213.

[7] H. Daly, "Uneconomic growth in theory and in fact", Feasta review 1, Dublin, 1999.

[8] S. Davoudi et al., "Planning for climate change. Strategies for mitigation and adaptation for spatial planners", Earthscan, London, 2009.

[9] H. Demsetz, "The Problem of Social Cost: What Problem? A Critique of the Reasoning of A.C. Pigou and R.H. Coase", Review of Law \& Economics, De Gruyter, vol. 7(1), February 2011, pp. 1-13.
[10] P. Duce et al., "Individuazione delle aree agricole e delle colture a forte rischio per variazioni climatiche", in CLIMAGRI: Cambiamenti climatici e agricoltura, Ministry of Agriculture and Forestry, Central Bureau of Agricultural Ecology, 2004, pp. 41-46.

[11] ESPON, "Climate Change and Territorial Effects on Regions and Local Economies (Climate)", Applied Research, Final Report 2011 Available from Internet: http://www.espon.eu/export/sites/default/Documents/Project s/AppliedResearch/CLIMATE/ESPON_Climate_Final_Rep ort-Part_B-MainReport.pdf.

[12] ESPON, "Science in support of European Territorial development and cohesion", Second ESPON Scientific Report, December 2013, Available from Internet: http://www.espon.eu/main/Menu_Publications/Menu_Scient ificReports/Second_Feb_2014.html.

[13] IPCC, "Climate Change 2013: the physical science basis", Working Group I, WG1, contribution to the fifth assessment report of the Intergovernmental Panel on Climate Change.

[14] ISTAT, "Conti regionali delle emissioni atmosferiche", Available from Internet: http://www.istat.it/it/archivio/53128

[15] K. W. Kapp, "The social costs of private enterprise. Schocken Books, New York, 1950.

[16] J. Knieling and L. Filo, "Climate change governance", Series: Climate Change Management, DOI: 10.1007/978 -3-642-29831-8_1, Springer-Verlag, Berlin, 2013.

[17] M. Koch, "Climate change, carbon trading and societal selfdefence", Real-world economics review, issue no. 67, 09 May 2014, pp. 52-66.

[18] J. Martinez-Alier and K Schupmann, " Ecological Economics energy, environment and society", Blackwell, Oxford, 1987.

[19] G. Pireddu, "Economia dell'ambiente", APOGEO, Milano, 2002.

[20] M. Prezioso, "Researching in geography beyond the spatial planning, matching science, theory and practice", in Science in support of European territorial development and cohesion. Second ESPON 2013 Scientific Report, ESPON, Luxembourg, 2013a, pp. 175-181.

[21] A. C. Pigou, "The Economics of Welfare", MacMillan \& Co., London, 1920.

[22] M. Prezioso and M. Coronato, "Sustainability in business practice: how competitiveness is changing in Europe", Journal of Multidisciplinary Research, 2013b, 5(1), 57-71.

[23] P. Schmidt-Thomé and S. Greiving, "European climate vulnerabilities and adaptation. A spatial planning perspective", Wiley Blackwell, West Sussex, Eds 2013.

[24] N. Stern, "The Economics of Climate Change. The Stern Review", Cambridge University Press, Cambridge, 2008.

[25] R. York, "Asymmetric effects of economic growth and decline on CO2 emissions", Nature Climate Change 2, 762-764, doi:10.1038/nclimate1699, 2012. 